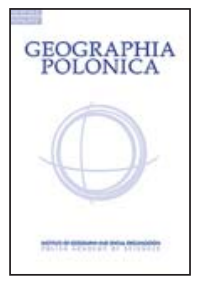

\title{
DURABILITY OF FOREST COVER IN THE OCHOTNICA VALLEY (GORCE MTS.) AND IN THE SOLINKA VALLEY (BIESZCZADY MTS.) IN THE 18TH-21ST CENTURIES
}

\author{
Janusz Godziek (D) - Bartłomiej Szypuła (D) \\ Faculty of Natural Sciences, Institute of Earth Sciences \\ University of Silesia in Katowice \\ Będzińska 60, 41-200 Sosnowiec: Poland \\ e-mails: j.godziek23@gmail.com (corresponding author) • bartlomiej.szypula@us.edu.pl
}

\begin{abstract}
Forests in the Carpathians are increasing their range mainly due to the expansion in former agricultural areas. In this study conducted for two valleys $\left(88\right.$ and $69 \mathrm{~km}^{2}$ ) topographical maps from 18th to 20th century and an orthophotomap were used in order to determine the durability of forest cover. This durability is understood as the period of time during which a given area was presumably occupied by forest. A digital elevation model (DEM) and a digital surface model (DSM) of $1 \times 1 \mathrm{~m}$ resolution were applied to investigate the relationship between forest cover durability and altitude, slope, aspect and the mean height of trees. The variety of spatial structure of forest cover durability results mainly from the differences of the examined valleys accessibility. Positive correlation between forest cover durability and the mean height of trees and altitude found for both valleys. A directly proportional relationship between forest cover durability and slopes also occurs in the Solinka Valley.
\end{abstract}

\section{Key words}

forest cover durability - Forest cover - Bieszczady Mts. • Gorce Mts. • digital elevation model • digital surface model $\bullet$ cartographic analysis

\section{Introduction}

Changes in land use and land cover are very dynamic nowadays (Bucała \& Starkel, 2013). In developed countries many mountain regions experience an increase in forest cover (Kozak, 2003; Szymura, Dunajski, \& Ruczakowska, 2010; Bebi et al., 2017). The main cause of this phenomenon is the abandonment of areas with unfavourable natural conditions for farming. Economic transformations cause a decline in profitability of agricultural production, which accelerates the process of farmland abandonment, especially in areas with low-quality soils and with a significant level of farmland fragmentation (Griffiths et al., 2014; Munteanu et al., 2014; Bucała-Hrabia, 2018; Godziek \& Szypuła, 
2018). In some areas an rise in woodiness can be caused by a random factor, e.g., by displacement of population and accompanying break in the continuity of settlement (Wolski, 2007; Affek, 2015).

In areas where a significant increase in forest cover occurs, forests can be divided into two categories. "Old forests" overgrow a given area for a very long time, while "new forests" are the effect of an increase in forest cover during last 100-150 years (Munteanu et al., 2015). New forests appear as a result of secondary succession on abandoned farmlands or as an effect of planned afforestation of agricultural wastelands. Research indicated that old forests are marked by greater biodiversity than new forests (Fritz, Gustafsson, \& Larsson, 2008; Orczewska, 2015). Therefore, delimitation of old forests area should be important in forest management and in planning forest protection (Skaloš, Engstová, Trpáková, \& Šantrůčková, 2012; Sabatini et al., 2018).

The study on forest cover development is also used in research into changes in hydrological and geomorphological processes in a given area (Bucała-Hrabia, 2018). There is a lot of evidence that an increase in forest cover limits soil erosion and contributes to a decrease of surface runoff (Bucała, 2012; Łajczak, Margielewski, Rączkowska, \& Świechowicz, 2014).

Historical cartographic materials are widely used in research on forest cover change (Augustyn \& Kucharczyk, 2008; Skaloš et al., 2012; Sobala, Rahmonov, \& Myga-Piątek, 2017). Some of research focuses on reconstructing forest cover extent (Szymura et al., 2010; Kaim et al., 2016) and on identifying factors that influence this extent with determining importance of particular factors (Kolecka et al., 2017). Another aim of such studies is finding correlation between forest cover and relief (Sobala \& Czajka, 2012; Godziek \& Szypuła, 2018), use mathematical modelling in order to predict future forest cover changes (Price et al., 2017) or use machine learning in order to define the probability of old forests occurrence (Sabatini et al., 2018). Some research deals with the occurrence of forest disturbances in old and new forests (Munteanu et al., 2015).

Research on forest cover has a lot of in common with research on landscape and landscape change. In mountainous areas, forests are one of the most important components of landscape, influencing its attractiveness (Plit, 2016). The extent of forest is important in visibility analysis (Nita et al., 2015) and in defining durability of particular landscapes. In the Polish Carpathians the durability of pastoral landscape has a significant meaning (Sobala, 2018). Thanks to historical cartographic materials we can try to date the period of time during which a given area was occupied by a particular kind of land use. In our research we use this approach to determine the durability of forest cover, which is understood as the period of time during which a given area was supposedly occupied by forest. Although the authors state age limits of the forest durability class (see Tab. 2), this should not be understood as the absolute age of the trees. The authors assumed the continuity of the forest occurrence if the forest cover in a given area was presented on two successively analyzed maps (older and newer). Naturally, this is a simplification, because it is not known exactly what happened with a given area between the releases of subsequent maps.

The objective of this research was to determine the durability of forest cover in the period 1780-2015 and to investigate the relationship between forest cover durability and the height of trees, altitude, slope and aspect. An indirect objective was identifying changes of woodiness in the period 1780-2015.

\section{Study Area}

The Beskids are mid- and low-mountains belonging to the Outer Carpathians. They stretch for $600 \mathrm{~km}$ through the Czech Republic, Slovakia, Poland and Ukraine, and their width reaches about 50-70 km (Kondracki, 2011). For detailed study two areas in the Polish Beskids were chosen: a part 
of the Ochotnica Valley (Fig. 1) located in the Gorce Mts. (Outer Western Carpathians) and a part of the Solinka Valley (Fig. 2) situated in the Bieszczady Mts. (Outer Eastern Carpathians) (Solon et al., 2018). The selected catchments occupy the area of $87.6 \mathrm{~km}^{2}$ and $68.7 \mathrm{~km}^{2}$ respectively and the distance between them reaches about $150 \mathrm{~km}$. Both areas are built from flysch sediments (alternating layers of sandstone and shale) belonging to Magura Nappe (Ochotnica Valley) and to Dukla Nappe (Solinka Valley) (Starkel, 1972).

The relief of Ochotnica Valley consists of numerous rounded ridges and a dozen of $\mathrm{V}$-shaped valleys converging to the main valley located latitudinally in the central part of the study area. Main ridges include: Gorc and Jaworzyna Kamienicka Ridge in the north and Lubań Ridge in the south. More than 75\% of Ochotnica Valley is occupied by steep slopes with inclination exceeding $15^{\circ}$. The relief in the Solinka Valley can be described as highly elevated rounded ridges with steep slopes and wide valleys with lesser slopes. Main ridges in this area include: centrally situated massif (Hyrlata) and a few ridges located close to the border of the study area (Wołosań Ridge, Jasło Ridge, Graniczne Ridge), while main valleys include the Solinka Valley and the Roztoczka Valley (the biggest tributary of Solinka). In the Solinka Valley steep slopes (above $15^{\circ}$ ) constitute about $60 \%$ of the area. Both areas have their lowest points located at the valley mouth, at the altitude of $481 \mathrm{~m}$ a.s.I. (Ochotnica Valley) and $556 \mathrm{~m}$ a.s.I. (Solinka valley). The highest point in the Ochotnica Valley is situated at the altitude of 1287 m a.s.l., while in the Solinka Valley - at 1152 m a.s.l. Local relief is higher in the Ochotnica Valley (exceeds $800 \mathrm{~m}$ ) than in the Solinka Valley, where it reaches nearly $600 \mathrm{~m}$. The average elevation of the Ochotnica Valley is situated at $821 \mathrm{~m}$ a.s.l., and in the Solinka Valley - at $782 \mathrm{~m}$ a.s.l.

The study area lies in moderate warm transitional climate, with a considerable influence of altitude a.s.I. (mountain climate). The impact of maritime air is the most significant during the year. In the Solinka Valley the influence of continental air is more meaningful than in the Ochotnica Valley. The highest precipitation occurs in summer. Mean annual precipitation on the ridges can exceed $1000 \mathrm{~mm}$. The study area is divided into three vertical climatic zones, which are compatible with vertical zones of vegetation. The lowest located zone (moderate warm), with the mean annual temperature above $+6^{\circ} \mathrm{C}$ occurs at the altitude below $700 \mathrm{~m}$ a.s.l. in the Gorce Mts. and below 500 m a.s.l in the Bieszczady Mts. It is occupied mainly by pastures, meadows, alder forest, birch forest or (rarely) by oak-hornbeam forest. The medium zone, named moderate cool, occurs at the elevation from 500 - 700 m a.s.l. to $1150 \mathrm{~m}$ a.s.l. The mean annual temperature in this zone varies between +4 and $+6^{\circ} \mathrm{C}$. The dominant forest type in the Gorce Mts. is mixed, beech-fir forest with admixture of spruce, while beech forest (the so-called Carpathian beech forest) dominates in the Bieszczady Mts. The highest zone (cool), with the mean annual temperature below $+4^{\circ} \mathrm{C}$, occupies areas located above $1150 \mathrm{~m}$ a.s.l. In the Gorce Mts. they are overgrown with spruce forest, while in Bieszczady Mts. there is dwarf beech forest which changes into mountain meadows (the so-called "połoniny") at higher altitudes (Czajka, 1987; Krukar, 2017; Sobala, 2018).

Contemporary settlements in the Ochotnica Valley appeared in the first half of 15th century, when Ochotnica village was established. As a result of its location in a very long valley, the village was split into Upper and Lower Ochotnica (Czajka, 1987). In the Solinka Valley colonisation took place circa 100 years later because of significant remoteness of this area caused by its location close to the border between Poland and Hungary. The villages of Liszna, Roztoki Górne, Żubracze and Solinka were founded in mid16th century. The cross-border situation of the Solinka Valley was unfavourable for settlements development and the villages were damaged two times in 17th century (Kryciński et al., 2017). 


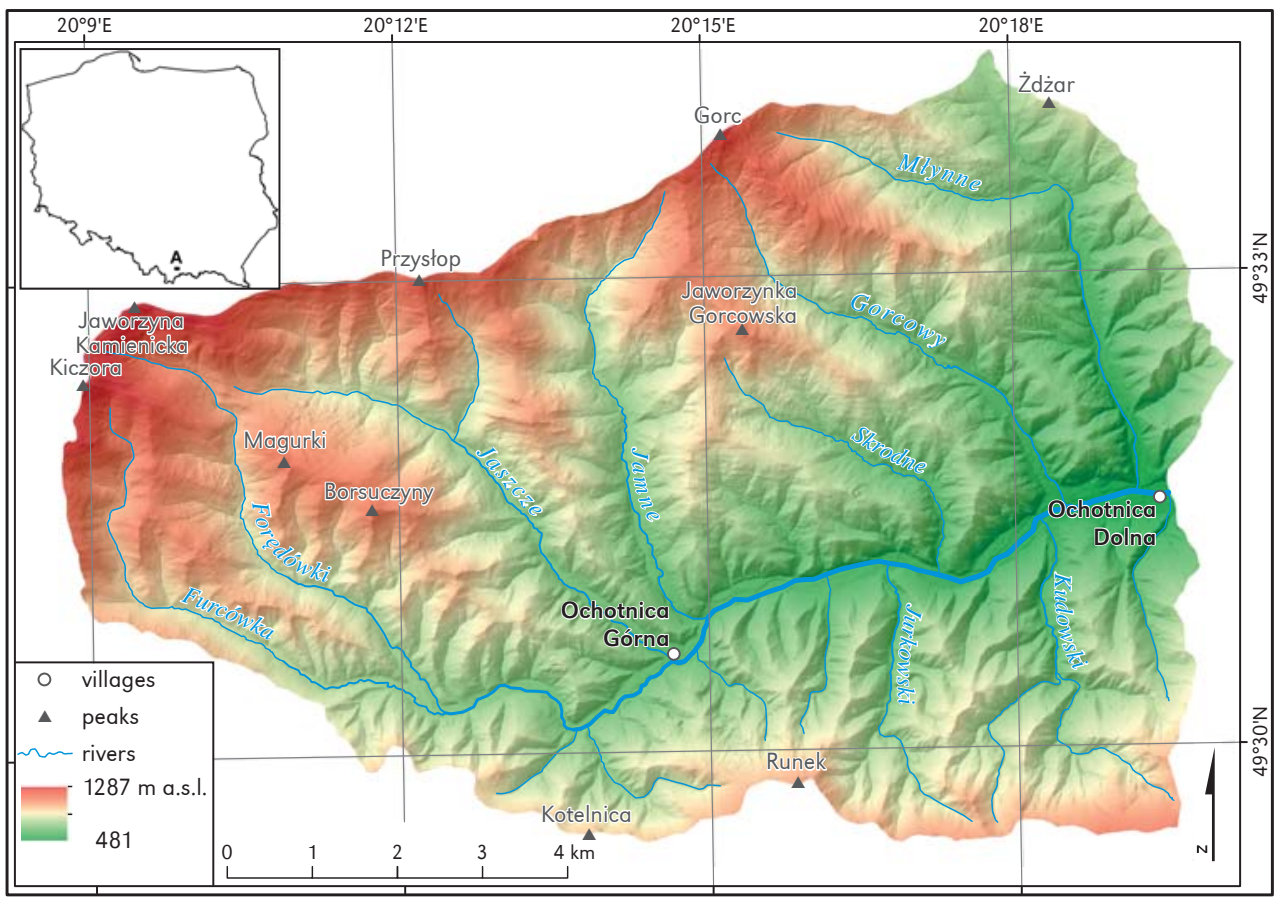

Figure 1. Hypsometry and location of the study area - Ochotnica Valley

People living in the Ochotnica and Solinka Valley cut forests in order to obtain land for agricultural purposes. They grazed sheep and cattle or cultivated oat, barley and potatoes. In 19th and at the beginning of 20th century the villages were overpopulated. A shortage of arable land and the development of industry caused an increase in emigration to cities. However, there was a systematic growth of population because of high birth rate. Demographic transition took place at the turn of 19th and 20th centuries (Soja, 2008). Untill mid-20th century the Ochotnica Valley was a significant centre of pastoral economy. Therefore, meadows reached highly located areas of slopes and ridges (Czajka, 1987). On the other hand, in 20th century in the Solinka Valley there was a narrowgauge railway, which was used for wood transport. This enabled forest owners to acquire wood more effectively (Rygiel, 2017).

In the Ochotnica Valley villages have been inhabited mainly by Polish highlanders and there has been no break in the continuity of settlement (Czajka, 1987). Before 1945 settlements in the Solinka Valley were populated by Ukrainian highlanders belonging to two ethnic groups: Lemkos and Boykos. After WWII on the basis of the agreement between Poland and USRR nearly all Ukrainians were displaced, mainly to USRR (Wolski, 2007). This break in the continuity of settlement caused a rapid decrease in population density and significant changes in land use and land cover, which are seen till today (Wolski, 2007; Soja, 2008; Affek, 2015).

\section{Source data}

The following maps and digital data sources were used during the analyses:

1. Topographic map of Galicia and Lodomeria at 1:28,800 scale (Karte des Königreiches Galizien und Lodomerien, 1779-1783). This was the so-called First Military Survey 


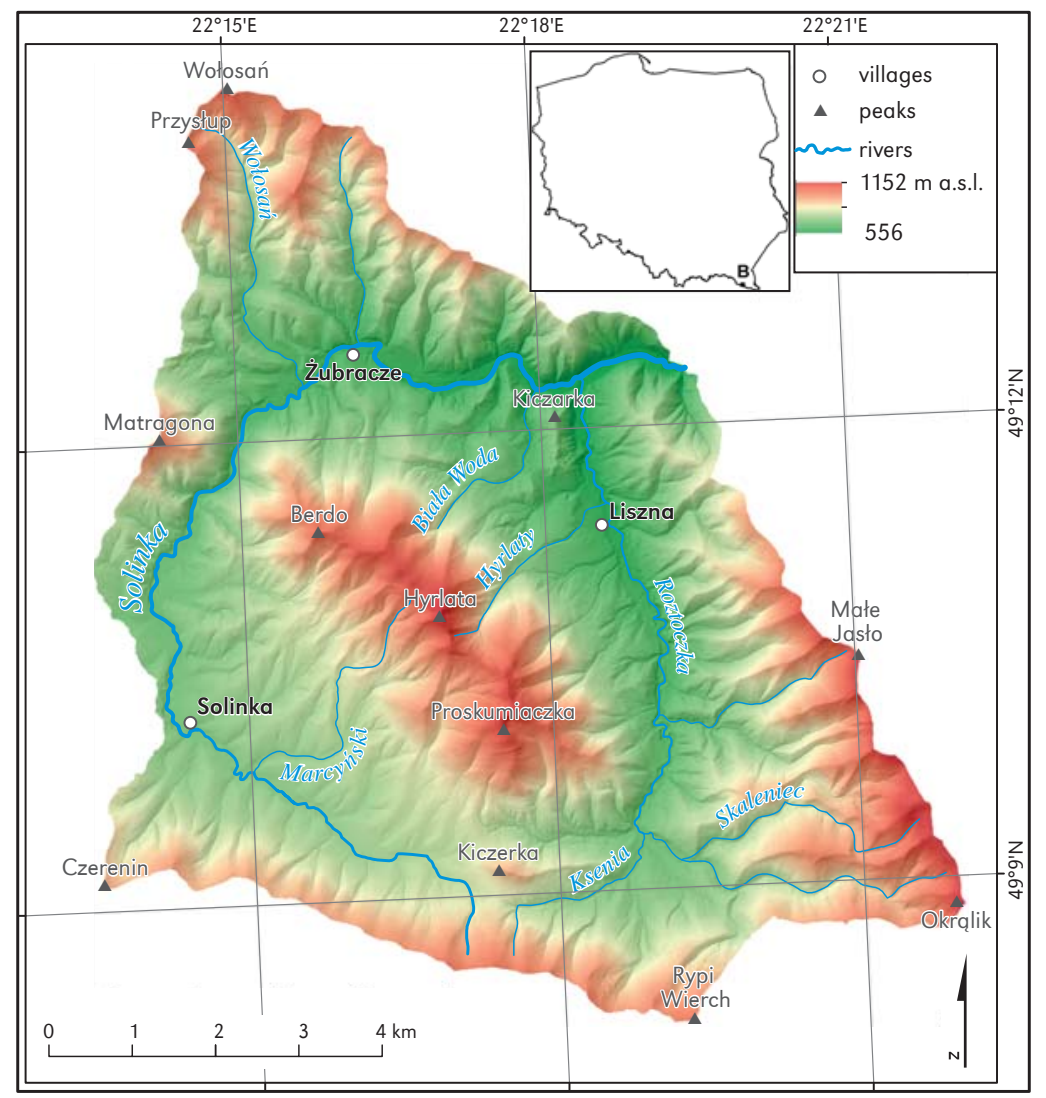

Figure 2. Hypsometry and location of the study area - Solinka Valley

of Habsburg Empire carried out without fundamental geodetic survey (no ellipsoid, no datum), but using the Liesganig triangulation and then executed graphically with plane tables and theodolites (Mastronunzio \& Dai Prà, 2016). The map consists of 413 sections of the $24 \times 16$-inch format $(63.2 \times 42.1 \mathrm{~cm})$. The works were based on older maps and table triangulation. The sheets do not contain a cartographic grid or geographic coordinates. The map was oriented not to the geographical north, but to the magnetic one (Wolski, 2016). Unfortunately, there is no legend in the form of a key of contractual signs. It can be presumed that detailed guidelines have never been created (e.g., non-uniformity of contractual signs and colors, as well as diversification of the drawing reflecting individual skills of cartographers). The importance of the First Military Survey lies not only in its precision, scale and detailed military-topographical descriptions, but also in the period of its origin. It gives us an opportunity to view the area just before the beginning of the industrial revolution, in the period of the full bloom of cultural baroque landscape and its highest diversity.

2. Topographic map of Galicia and Bukovina at 1:28,800 scale (Militär Aufnahme von Galizien und der Bukovina, 18611864). This was the so-called Second Military Survey of Habsburg Empire. This map was based on a triangular net (detailed trigonometric measurements) and also on the cadastral maps of Stabile Cadaster in the scale of $1: 2,880$, therefore, its 
precision is much higher. Using triangulation points, altitude points (topographic and table positions) were determined and used for interpolation of contour lines, which, in turn, were an auxiliary matrix of a relief drawing made according to the modified Lehmann scale (Wolski, 2016). Besides larger scale maps (1: 28,800), also the so-called general (1: 288,000) and special $(1: 144,000)$ maps were produced (Affek, 2013). The map consists of 465 sections of the $20 \times 20$-inch format (52.7 $\times$ $52.7 \mathrm{~cm})$. The content of the sheets is in fact identical with the previous work, with an addition of triangular points altitudes, but the recorded situation is very different. The 2nd Military Survey was carried out at the time when the industrial revolution was in progress and intensive forms of agriculture were employed widely.

3. Tactical map of Poland at 1:100,000 scale (Mapa taktyczna Polski, 1934-1938). This map was developed and printed by the Military Geographical Institute (Wojskowy Instytut Geograficzny) to satisfy the military and economic needs of Poland at that time. For the map quasi-geographical WIG projection was adopted, with minimal distortions of the system near the center of Poland, at the intersection of the parallel of $52^{\circ} \mathrm{N}$ with the $22^{\circ} \mathrm{E}$. The center of the projection received the following coordinates: $x=+500,000 \mathrm{~m}, \mathrm{y}=+600,000 \mathrm{~m}$. This way the points obtained positive coordinates in the entire mapping area. Rectangular construction of the grid at intervals of two kilometers and described every four kilometers facilitated the determination of the position of points on the map. The relief was depicted by contours every $20 \mathrm{~m}$. All map sheets had a uniform size: $15^{\prime}$ latitude and $30^{\prime}$ longitude (Katalog map 1938). A total of 482 sheets were issued.

4. Topographic map at 1:25,000 scale (Mapa topograficzna, 1978-1982). It was a map for economic purposes, which was developed in the years 1962-1989 by rewriting and generalizing a topographical map at 1:10,000 scale in the 1965 coordinate system (EPSG: 3120$)$ and was published in a two or four-color version. Part of the sheets was compiled on the basis of updated 1:25,000 map sheets in the 1942 coordinate system (EPSG: 3334). On these maps there is no cartographic grid, only a kilometer grid. The relief was depicted by contours every $5 \mathrm{~m}$. Until 1990 this map covered about $75 \%$ of Poland (Kowalski \& Siwek, 2013).

5. Orthophotomap with pixel resolution of $0.25 \times 0.25 \mathrm{~m}$ (Orthophotomap, 20152018). A digital orthophotomap is a raster, cartometric image of the area created as a result of orthogonal processing of aerial photographs or satellite scenes carried out in 2015-2018. Orthophotomaps are made in a flat rectangular coordinate system 1992 (EPSG: 2180) or 2000 (EPSG: 2178 ) in real colors (RGB) (GUGiK, 2019).

6. Digital elevation model DEM (NMT, 2014) and digital surface model DSM (NMPT, 2014). All these elevation data were surveyed in a flat rectangular coordinate system 1992 (EPSG: 2180) and the heights refer to the normal height system "Kronsztadt 86". These digital data are in Arc/Info ASCII Grid format with the $1 \times 1 \mathrm{~m}$ resolution and they were interpolated on the basis of a point cloud from airborne laser scanning (LIDAR) made in 2012. The average height error is in the range of 0.2 m (GUGiK, 2019).

\section{Methods}

The work related to the analysis of the studied areas can be divided into several basic stages. The first step was to define study sites - catchment areas of small rivers in the Carpathians in southern Poland. At this stage, a shaded relief model based on DEM (NMT, 2014) was used to correctly determine catchment boundaries for each studied area.

After collecting historical cartographic materials it was necessary to prepare them appropriately for work in the GIS environment. The preparation consisted in giving 
georeferences and bringing all materials to one coordinate system. Topographic maps 1:25,000, an orthophotomap, a digital elevation model and a digital surface model were obtained in a flat rectangular coordinate system 1992 (EPSG: 2180), so it was not necessary to give georeferences. The Tactical Map of Poland (Mapa taktyczna Polski 1934-1938) was downloaded from MAPSTER service (MAPSTER, 2019) and then fully georeferenced using ArcGIS (ESRI, 2018) with Georeferencing tool and Adjust function.

When it comes to the oldest two maps (Karte des Königreiches Galizien und Lodomerien 1779-1783; Militär Aufnahme von Galizien und der Bukovina 1861-1864) - they were obtained from the MAPIRE site by WMS service (MAPIRE, 2019). Theoretically, these maps had already been prepared and subjected to the process of georeference to the WGS84 coordinate system (EPSG: 4326) (Molnár \& Timár, 2009; Podobnikar, 2009; Timár \& Biszak, 2010). Unfortunately, while working in the GIS software, it turned out that location errors (shifts) are very large. It is in line with the analyses of other researchers (Pietkiewicz, 1975; Konias, 2000): the average absolute distance errors on the Karte des Königreiches Galizien und Lodomerien (1779-1783) map (in relation to the base distances measured on contemporary topographic maps) are strongly varied, from 150 to $1000 \mathrm{~m}$, and the average errors of the direction and angle on an identical transect increase from about $1^{\circ}$ to $4^{\circ} 50^{\prime}$. Timár, Biszak, Szekely, and Molnár (2011) noted that in case of smaller provinces the average accuracy is around 500 meters, while the maximum error is circa 2 kilometers. The corresponding values for larger provinces are even 1-4 kilometers (sic!). On the other hand, the accuracy of the Militär Aufnahme von Galizien und der Bukovina (1861-1864) is far better than the first one; it exceeds 200 meters in most cases, while for the most populated and important parts of the Empire it is between 50 and 100 meters. In case of Tyrol and Salzburg, however, the maximum errors are 220 and 500 meters respectively (Timár, 2009).
Moreover, the error vectors stated by Molnár, Timár, and Biszak (2014) are not systematic, so they cannot be modelled by simple mathematic methods available in GIS packages.

In the light of the above information, it was decided to adapt of both Galicia's maps at the scale $1: 28,800$ to the methods used in GIS systems using georeferencing procedures with the function Georeferencer and Spline in QGIS (QGIS Development Team, 2019) and next using Georeferencing and Adjust function in ArcGIS (ESRI, 2018). In order to check the location accuracy of the three calibrated maps, 30 control points were selected for both study areas (Fig. 3). The points were located in such a way that they were both evenly distributed over the entire area and could be unambiguously identified on historical maps. The points were located mainly: at summits, crossroads, places with river forks or tributary flowing into the main river. The measured shift errors are shown in Table 1.

As one can see, the Tactical Map of Poland (Mapa taktyczna Polski, 1934-1938) has the best accuracy, despite the smallest scale $(1: 100,000)$, with the average location errors of about $50 \mathrm{~m}$. The oldest map (Karte des Königreiches Galizien und Lodomerien, 1779 1783) has the worst accuracy, the average shift error varies between 170 and $190 \mathrm{~m}$.

Apart from the issues of absolute location accuracy, it should be clearly stated that archival medium-scale topographic maps of Galicia are an invaluable source of information, because they record with great detail the natural and socio-economic landscape of this area at that time (Prokop, 2017). Thus, it is a unique cartographic study that enables us to conduct a relatively reliable and accurate reconstruction of the state of the geographical environment from much earlier times (Wolski, 2016).

The next important step was vectorization of forest cover ranges from all the maps and the orthophotomap, as well as preparation to analyse raster data coming from DEM and DSM. Vectorization was held manually, using on screen method. Elevation, slope 
Table 1. Shift errors in meters on the georeferenced historical maps

\begin{tabular}{|c|c|c|c|c|c|c|c|c|c|c|c|c|}
\hline \multirow[t]{2}{*}{$\begin{array}{l}\text { Study } \\
\text { site }\end{array}$} & \multicolumn{4}{|c|}{$\begin{array}{c}\text { Karte des Königreiches Galizien } \\
\text { und Lodomerien } \\
(1779-1783) \\
1: 28,800\end{array}$} & \multicolumn{4}{|c|}{$\begin{array}{c}\text { Militär Aufnahme von Galizien } \\
\text { und der Bukovina } \\
(1861-1864) \\
1: 28,800\end{array}$} & \multicolumn{4}{|c|}{$\begin{array}{c}\text { Mapa taktyczna Polski } \\
(1934-1938) \\
1: 100,000\end{array}$} \\
\hline & $\min$ & $\max$ & mean & SD & $\min$ & $\max$ & mean & SD & $\min$ & $\max$ & mean & SD \\
\hline Ochotnica & 15 & 535 & 171 & 120.0 & 30 & 123 & 61 & 22.0 & 5 & 98 & 55 & 23.4 \\
\hline Solinka & 27 & 491 & 189 & 111.6 & 47 & 253 & 116 & 55.4 & 14 & 120 & 51 & 26.9 \\
\hline
\end{tabular}
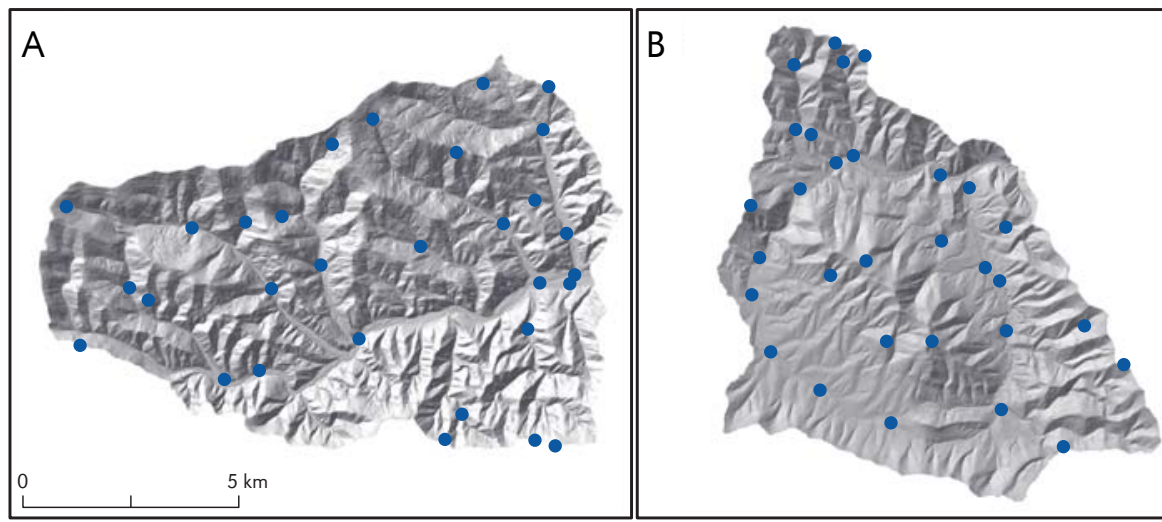

Figure 3. Spatial distribution of the control points at the Ochotnica Valley (A) and Solinka Valley (B)

and aspect rasters were reclassified according to classes assumed for the analysis (see Tab. 3-5). Raster describing the height of trees was calculated as a difference between DSM and DEM with the use of Raster Calculator function. All raster data described above were prepared in $1 \times 1 \mathrm{~m}$ resolution.

The next stage of work was determination of ranges of forest areas with particular durability. This process was based on vector layers presenting ranges of forest in particular years and was held with the use of intersect, erase and union tools. Age limits of particular forest cover durability classes were determined on the basis of topographical currency of cartographic data. Taking into consideration the differences in topographical currency of maps in both valleys and lack of accurate data relating to the datum of realisation of a given map sheet, it was decided to assume a reference year. Age limits of particular forest durability classes were calculated for 2015 and reference years (Tab. 2).

In order to determine areas uninterruptedly occupied by forest during a given period (1780-2015, 1865-2015, 1935-2015, 1980-2015), common parts of areas overgrown by forest in years belonging to a given period were extracted. In this way, layers delimitating the range of forest with durability $>235$ years, $>150$ years, $>80$ years and $>35$ years were obtained. The next step was isolation of forest areas belonging to a particular forest durability class. In order to determine the area of forest belonging to durability class of $150-235$ years the layer marking the range of forests with durability $>235$ years was subtracted from the layer marking the range of forests with durability $>150$ years. An analogical course of proceedings was applied in the determination of ranges of remaining forest durability classes. The last stage was creation of one 
Table 2. Topographical validity of used materials and age limits of forest durability classes

\begin{tabular}{|c|c|c|c|}
\hline \multicolumn{2}{|c|}{ Topographical validity } & \multirow{2}{*}{$\begin{array}{c}\text { Reference } \\
\text { year }\end{array}$} & $\begin{array}{c}\text { Age limit } \\
\text { of forest durability class }\end{array}$ \\
\cline { 1 - 2 } Ochotnica & Solinka & 1780 & 235 \\
$1779-1783$ & $1779-1783$ & 1865 & 150 \\
$1861-1864$ & $1861-1864$ & 1935 & 80 \\
1934 & $1937-1938$ & 1980 & 35 \\
$1978-1979$ & 1982 & 2015 & 0 \\
2015 & 2015 & & \\
\hline
\end{tabular}

vector layer presenting ranges of all forest cover durability classes. The above activities were automatized with the use of ModelBuilder tool available in ArcGIS software (ESRI, 2018).

The determination of ranges of forest cover durability allowed us to lead further works mainly consisting in the analysis, during which the occurrence of particular durability classes according to altitude, slopes and aspect was examined. For this purpose, percentage share of areas belonging to a particular class of altitude, slopes and aspect was calculated. Medium value of the height of trees and inclination for areas occupied by particular forest durability classes were extracted with zonal statistics tool. Percentage share of particular forest durability classes in forest cover area was determined, whereby forest cover area in 2015 was assumed as $100 \%$. For all forest cover ranges delimitated in both valleys, shares of area occupied by forest cover in the total area of the valley were calculated and forest cover durability maps for 2015 were made.

\section{Results and discussion}

\section{Changes of forest cover in the period $1780-2015$}

During the analysed period of time forest cover underwent various changes (Fig. 4). Till the second half of 19th century the share of forest cover was slowly decreasing and it reached a minimum range around 1865 . In the next 70 years a gradual increase in forest cover was noted, nevertheless, before 1940s forest ranges were quite stable. A sudden increase in the share of area occupied by forest cover occurred after WWII and has remained since then. In both areas the biggest increase, reaching about 17\%,

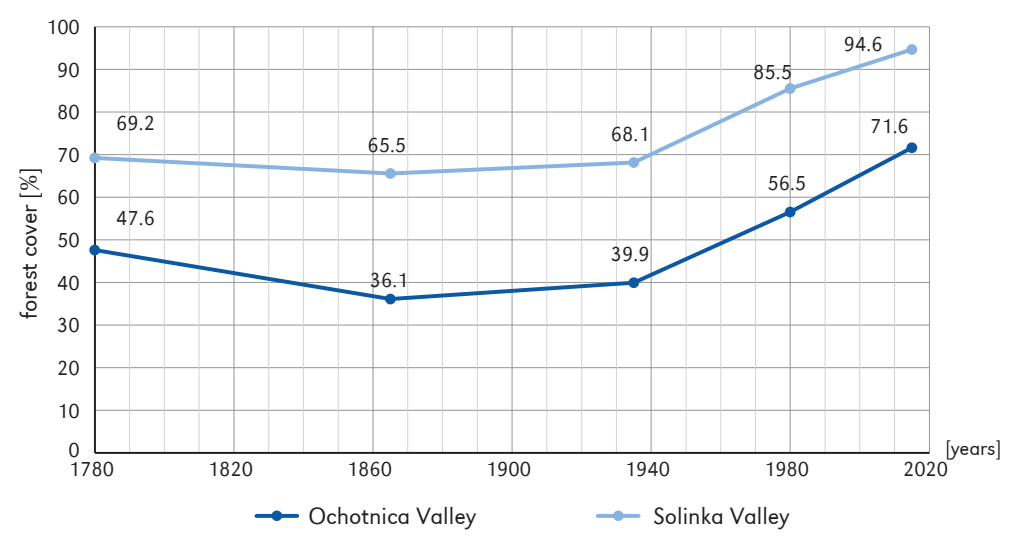

Figure 4. Forest cover changes in both valleys in the period 1780-2015 
was noted in the period 1935-1980. Generally, during all the examined period forest cover was greater in the Solinka Valley than in Ochotnica Valley. The difference between these two areas was quite stable and fluctuated between $21 \%$ and $29 \%$.

Changes of forest cover detected in both study sites reflect transitions described in the Carpathians (Kozak, 2003; Bucała, 2012; Munteanu et al., 2014; Sobala et al., 2014; Kolecka et al., 2017) and in other mountains around the world (Szymura, 2010; Skaloš, 2012; Bebi et al., 2017; Price et al., 2017). The dynamic growth of forest cover area from 1930s is caused by socio-economic changes, such as the increased mobility of the local population from the second half of 19th century and the development of off-farm employment, which decreased the significance of agriculture. As a decline in grazing and development of tourism, nature conservation and forestry occurred. In the Ochotnica Valley these processes were accompanied by population growth (Czajka, 1987), while in the Solinka Valley the displacement of inhabitants caused the acceleration of forest expansion (Wolski, 2007).

During all the examined period the share of forest cover in the Solinka Valley was more than 20\% greater than in the Ochotnica Valley. It is caused by significant remoteness, which contributed to the differences in the course of settlement processes and the development of agriculture between both valleys. The Solinka Valley is adjacent to the border, while the distance between the border and the Ochotnica Valley totals circa $15 \mathrm{~km}$. First settlements in the Ochotnica Valley were established circa 100 years earlier than in the Solinka Valley. In the Ochotnica Valley there was no break in the continuity of settlement, while two such breaks (in 2nd half of 17th century and after 1945) occurred in the Solinka Valley. During 19th and first half of 20th century the Ochotnica Valley was a big centre of pastoral economy (Czajka, 1987; Kryciński et al., 2017). The abovementioned facts explain the difference in forest cover between both valleys.

\section{Forest durability classes - spatial distribution and structure}

Forest cover durability maps (Fig. 5 and Fig. 6) and graphs presenting forest cover durability structure (Fig. 7) were prepared on the basis of cartographical analysis of forest cover ranges in particular periods. It made it possible to compare forests between the two analysed areas.

Forests in the Ochotnica Valley are significantly fragmented and there are a lot of disturbances in the continuity of forest caused by the occurrence of meadows and pastures (Fig. 5). Forests with a long period of durability occupy dense areas in northwest part of the valley, located in upper parts of Furcówka, Forendówka and Jaszcze catchments. Scattered areas of this kind of forests occur also in the northern part of the valley, close to Gorc massif, and in the southern part, in Luban Ridge. Forest with short durability period are present on the slopes located closer to the valley bottom or in the surroundings of former meadows, when secondary succession takes place. The share of particular forest durability classes is even (Fig. 7). Forests with durability period shorter than 80 years and forests with durability period longer than 235 years account for nearly $80 \%$ of the Ochotnica Valley. Low share of forest durability class from 150 to 235 years confirms that this period witnessed a decrease in forest cover.

In the Solinka Valley forests with durability period longer than 150 years occupy nearly $65 \%$ of the area (Fig. 7). They occur as dense forest complexes in Hyrlata massif and in Wołosań and Jasło Ranges (Fig. 6). The second and third biggest share belongs to durability periods shorter than 80 years. These forests mainly occupy the areas located in the valley bottoms in places of former farmlands and villages. The share of forests with durability period shorter than 35 years is the biggest in former Solinka village. In other villages forest durability class from 35 to 80 years dominates. Forests of short durability period occur also on the ridges, where secondary 


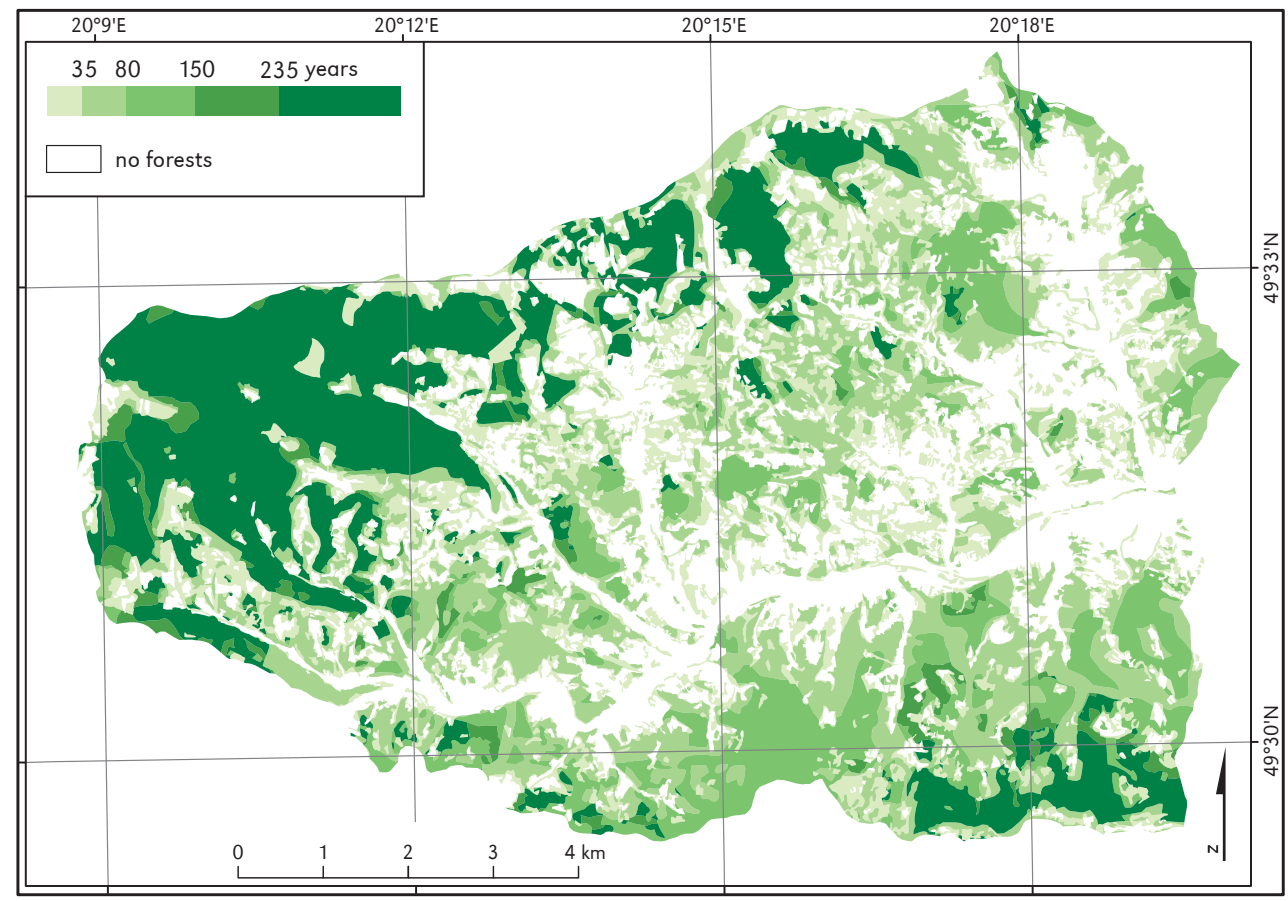

Figure 5. Forest cover durability in the Ochotnica Valley

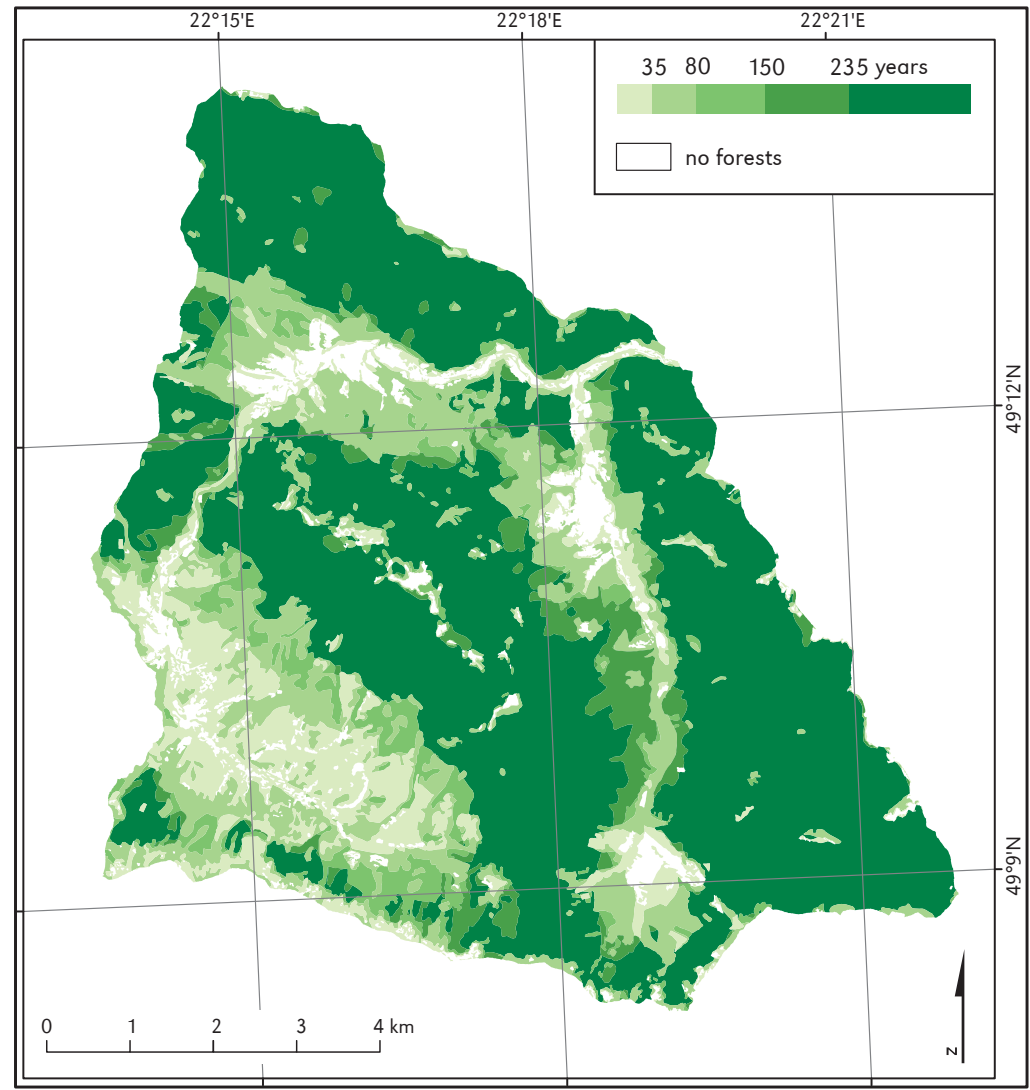

Figure 6. Forest cover durability in the Solinka Valley 
succession overgrows former meadows. A relatively low share of durability classes from 80 to 150 years and from 150 to 235 years suggests significant stability in forest cover in 18th and 19th centuries.
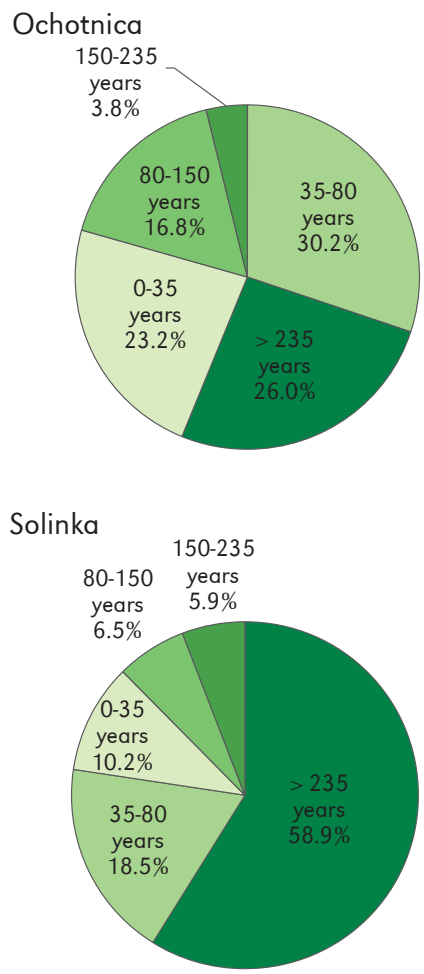

Figure 7. Forest cover durability structure in the Ochotnica Valley and in the Solinka Valley

Munteanu et al. (2015) proved that in the Carpathians forest disturbances occur more often in areas forested after 1860 than in old forests, growing in a given area longer than from 1860. This conclusion can be confirmed in the case of the Ochotnica Valley, where new forests with durability period shorter than 150 years are significantly fragmented by former meadows and pastures. In both study sites the majority of old forests are dense and devoid of big amount of forest disturbances. In the Solinka Valley the share of old forests is significantly greater than in the Ochotnica Valley. It is connected with the remoteness of the Solinka Valley. Sabatini et al. (2018) concluded that old forests occur most often in remote and scarcely populated areas, mostly located in mountains. This research confirms that the more inaccessible an area, the bigger share of old forests.

\section{Relationship between forest cover durability and mean height of trees}

In both examined areas a directly proportional relationship between forest durability classes and mean height of trees was detected (Fig. 8). In forests with the shortest durability period the mean height of trees does not exceed $10 \mathrm{~m}$, while in forests with durability period longer than 235 years it reaches $14.8 \mathrm{~m}$ for the Ochotnica Valley and $18.2 \mathrm{~m}$ for the Solinka Valley. For all forest durability classes the mean height of trees is bigger in Solinka Valley than in Ochotnica Valley and the difference between them fluctuates from 0.7 to $4.2 \mathrm{~m}$. The difference between the mean heights of trees for the forests of the longest and the shortest durability period totals $8.00 \mathrm{~m}$ for the Ochotnica Valley and $9.05 \mathrm{~m}$ for the Solinka Valley. It should be noted that an increase in the mean height of trees between neighbouring forest durability classes is not considerable. It reaches maximally $4 \mathrm{~m}$ for the Ochotnica Valley and fluctuates between 1.6 and 3.4 for the Solinka Valley. In the Ochotnica Valley a decrease in the mean height of trees occurs between forest durability classes of $35-80$ years and 80-150 years.

The height of trees can be conditioned by many factors, such as altitude, climate, dominating tree species, amount of wood sourced in a given area, health status of trees, presence of protected areas, etc. The results of this study confirm that the length of a period during which a given area was overgrown by forests is also important. The height of trees obtained from DSM can be used in the detection of areas of abandoned agricultural land overgrown by secondary forest succession (Kolecka et al., 2015). Forest in such areas has short durability period and in most of cases trees are lower than those growing in forests 

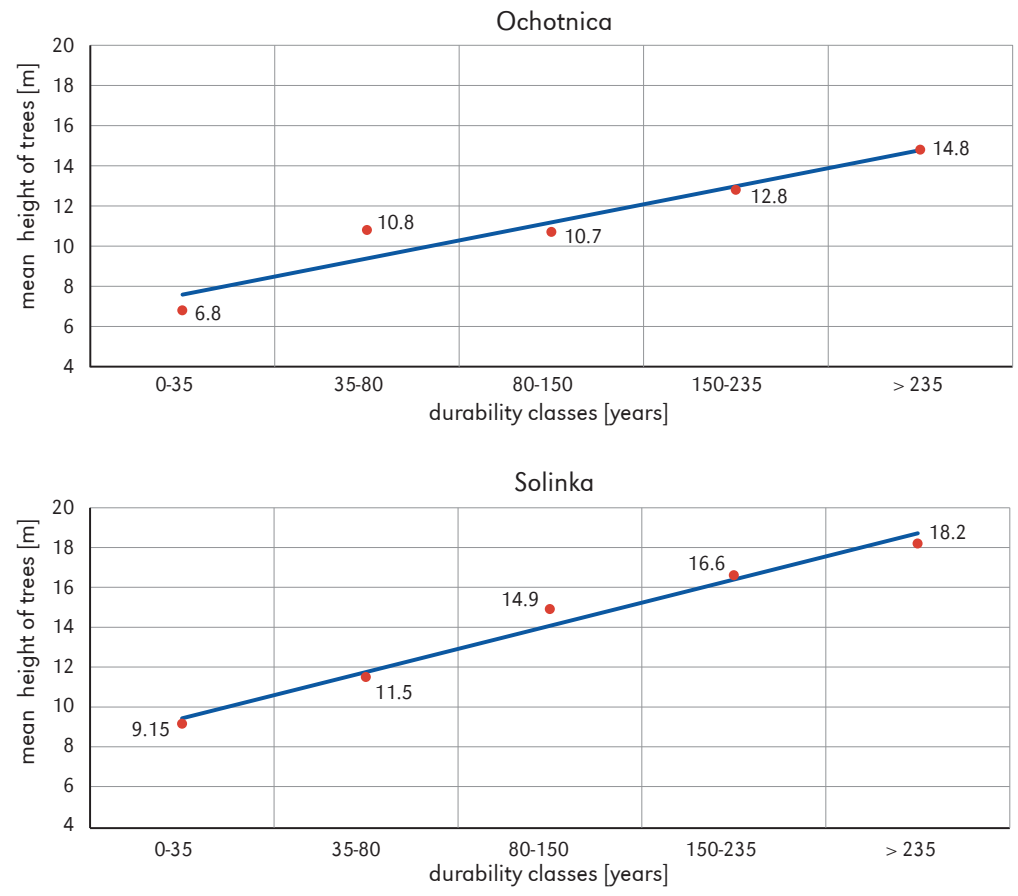

Figure 8. Mean height of trees according to forest durability classes

with a longer durability period. In both valleys values of mean height of trees in forest durability class above 235 years are relatively low in comparison with values noted for forests with dominating share of old, mature trees (Antonarakis, Richards, \& Brasington, 2008). Main cause of lowering of medium value are climatic conditions. Forest with long durability period very often overgrow areas located at high altitudes, where, height of trees is smaller due to more severe climate.

\section{Relationship between forest cover durability and relief}

During the conducted analysis an attempt to find relationships between forest cover durability classes and relief described by derivatives of DEM (slope, aspect and altitude) was taken.

A positive correlation between forest durability classes and mean slopes was observed in the Solinka Valley, while in the Ochotnica Valley these two variables are not related to each other (Fig. 9). In the Solinka Valley minimal mean slopes $\left(9.6^{\circ}\right)$ occur in forests of the shortest durability period and maximal mean slopes of $21.7^{\circ}$ are related to forests of the longest durability period. The difference between them reaches $12.1^{\circ}$ and the increase in the mean slopes between neighbouring durability classes varies from $1.6^{\circ}$ to $3.9^{\circ}$. In the Ochotnica Valley the value of mean slopes is similar for all forest durability classes and fluctuates in a very narrow range (between $20.5^{\circ}$ and $23.1^{\circ}$ ).

A similar situation can be observed when percentage share of slope ranges in areas occupied by several forest durability classes is compared (Tab. 3). In the Ochotnica Valley in all forest durability classes slope class $15-35^{\circ}$ prevails and its share varies between 70.8 and $79.3 \%$. The shares of other slope classes are also quite stable for all forest durability classes. In the case of the Solinka Valley, the longer forest durability period, the bigger share of greater slopes. This relationship is particularly visible for slope 

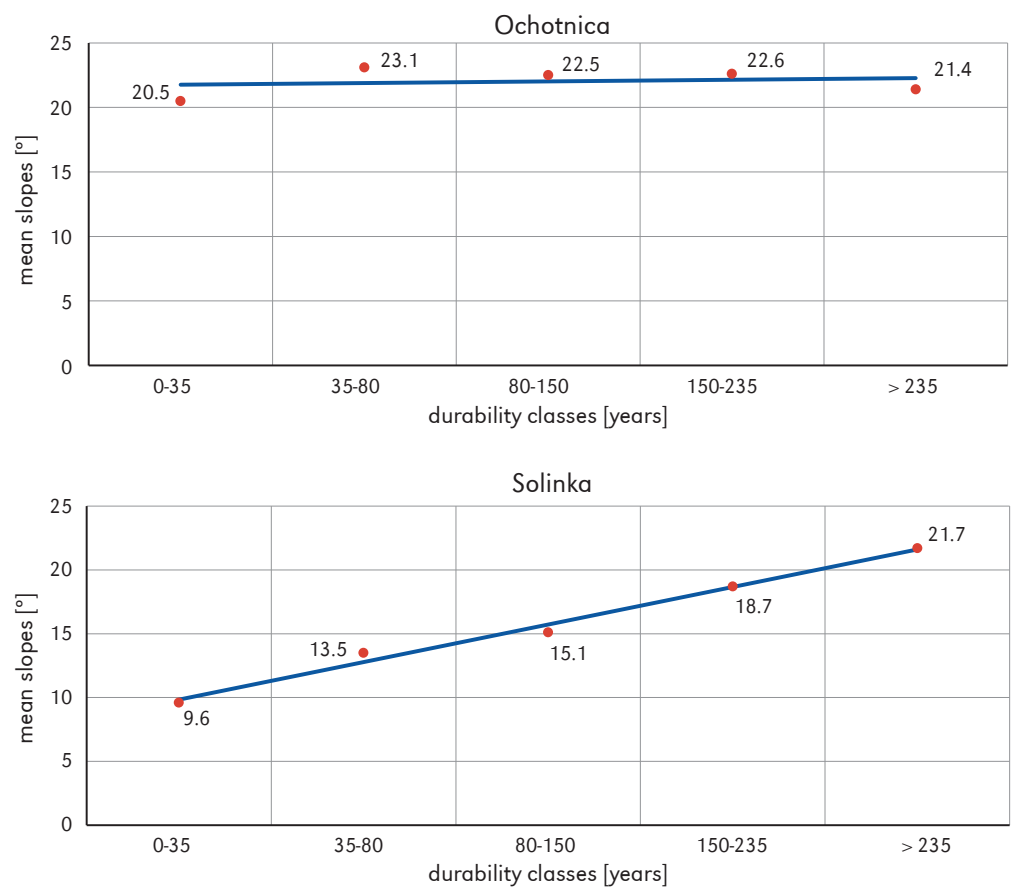

Figure 9. Mean slopes according to forest durability classes

class $15-35^{\circ}$, whose percentage share rises gradually from $14.9 \%$ (for forests of durability below 35 years) to $77.2 \%$ (for durability class above 235 years). On the other hand, the share of the lowest slope class $\left(0-2^{\circ}\right)$ decreases from $5 \%$ in forests of the shortest durability to $0.1 \%$ in forests of the longest durability.

In both valleys the percentage share of areas occupied by several aspects is similar in every forest durability class (Tab. 4). The share of several aspects fluctuates between 17.6 and $35.2 \%$ in the Ochotnica Valley and between 14.1 and $39.2 \%$ in the Solinka Valley. The lowest share of $W$ aspect (in three durability classes) and of $S$ aspect (in two durability classes) is noted in the Ochotnica Valley. In this area the biggest share belongs to $\mathrm{N}$ aspect (35.2\% in durability class $80-150$ years) and to S aspect (circa 30\% in first and last durability class). In the Solinka Valley the lowest shares belong to $S$ aspect (in three durability classes) and to $E$ aspect (in two durability classes). The biggest shares are reached by $\mathrm{W}$ and $\mathrm{N}$ aspects (both of them in two durability classes), but the maximum share (39.2\%) belongs to $E$ aspect in the durability class of 150-135 years. Nevertheless, there is no correlation between the share of several aspects and forest durability classes.

In the case of relationship between forest durability classes and altitude (Tab. 5) it can be observed that in both valleys the areas of forests with long durability period occur on higher altitudes than areas occupied by forests with short durability period. In the Ochotnica Valley the share of areas located above $800 \mathrm{~m}$ a.s.l. is the lowest in forest durability class from 35 to 80 years and the highest in classes of durability of above 150 years. In the Solinka Valley areas located above $800 \mathrm{~m}$ a.s.l. have the biggest share in two forest durability classes: above 235 years and from 80 to 150 years, while their lowest share occurs in forests of durability below 80 years. In both valleys the percentage share of areas situated below $600 \mathrm{~m}$ a.s.l. is the biggest 
Table 3. Areas of forest durability classes according to slopes

\begin{tabular}{|c|c|c|c|c|c|c|c|c|c|c|c|c|}
\hline \multirow{3}{*}{$\begin{array}{c}\text { Slopes } \\
{\left[{ }^{\circ}\right]}\end{array}$} & \multicolumn{6}{|c|}{ Ochotnica Valley } & \multicolumn{6}{|c|}{ Solinka Valley } \\
\hline & \multirow{2}{*}{$\begin{array}{c}\text { entire } \\
\text { area } \\
{[\%]}\end{array}$} & \multicolumn{5}{|c|}{ forest durability classes [\%] } & \multirow{2}{*}{$\begin{array}{c}\text { entire } \\
\text { area } \\
{[\%]}\end{array}$} & \multicolumn{5}{|c|}{ forest durability classes [\%] } \\
\hline & & $0-35$ & $35-80$ & $80-150$ & $150-235$ & $>235$ & & $0-35$ & $35-80$ & $80-150$ & $150-235$ & $>235$ \\
\hline $0-2$ & 1.1 & 0.4 & 0.2 & 0.1 & 0.1 & 0.1 & 1.4 & 5.0 & 1.4 & 0.6 & 0.3 & 0.1 \\
\hline $2-7$ & 5.1 & 3.8 & 2.0 & 1.7 & 1.3 & 2.0 & 11.7 & 38.4 & 19.3 & 11.8 & 5.7 & 2.3 \\
\hline 7-15 & 20.3 & 20.5 & 12.6 & 14.0 & 15.1 & 16.8 & 26.6 & 40.0 & 43.9 & 41.6 & 29.0 & 16.1 \\
\hline $15-35$ & 69.5 & 70.8 & 79.3 & 79.4 & 78.2 & 77.1 & 56.9 & 14.9 & 32.8 & 43.7 & 60.5 & 77.1 \\
\hline$>35$ & 4.0 & 4.5 & 5.9 & 4.8 & 5.3 & 4.0 & 3.4 & 1.7 & 2.6 & 2.3 & 4.5 & 4.4 \\
\hline Total & 100.0 & 100.0 & 100.0 & 100.0 & 100.0 & 100.0 & 100.0 & 100.0 & 100.0 & 100.0 & 100.0 & 100.0 \\
\hline
\end{tabular}

Table 4. Areas of forest durability classes according to aspect

\begin{tabular}{|c|c|c|c|c|c|c|c|c|c|c|c|c|}
\hline \multirow{3}{*}{ Aspect } & \multicolumn{6}{|c|}{ Ochotnica Valley } & \multicolumn{6}{|c|}{ Solinka Valley } \\
\hline & \multirow{2}{*}{$\begin{array}{c}\text { entire } \\
\text { area } \\
{[\%]}\end{array}$} & \multicolumn{5}{|c|}{ forest durability classes [\%] } & \multirow{2}{*}{$\begin{array}{c}\text { entire } \\
\text { area } \\
{[\%]}\end{array}$} & \multicolumn{5}{|c|}{ forest durability classes [\%] } \\
\hline & & $0-35$ & $35-80$ & $80-150$ & $150-235$ & $>235$ & & $0-35$ & $35-80$ & $80-150$ & $150-235$ & $>235$ \\
\hline$N$ & 24.4 & 22.2 & 25.7 & 35.2 & 27.2 & 23.8 & 27.9 & 28.3 & 34.6 & 31.9 & 29.8 & 24.7 \\
\hline $\mathrm{E}$ & 28.0 & 28.9 & 26.8 & 19.5 & 24.2 & 26.5 & 21.6 & 17.2 & 23.8 & 22.6 & 39.2 & 19.4 \\
\hline S & 28.1 & 31.3 & 26.3 & 17.6 & 20.8 & 29.0 & 23.7 & 24.0 & 15.6 & 19.6 & 16.9 & 27.7 \\
\hline W & 19.5 & 17.6 & 21.2 & 27.7 & 27.8 & 20.7 & 26.8 & 30.5 & 26.0 & 25.9 & 14.1 & 28.2 \\
\hline Total & 100.0 & 100.0 & 100.0 & 100.0 & 100.0 & 100.0 & 100.0 & 100.0 & 100.0 & 100.0 & 100.0 & 100.0 \\
\hline
\end{tabular}

Table 5. Areas of forest durability classes according to altitude

\begin{tabular}{|c|c|c|c|c|c|c|c|c|c|c|c|c|}
\hline \multirow{3}{*}{$\begin{array}{l}\text { Altitude } \\
\text { [m a.s.l] }\end{array}$} & \multicolumn{6}{|c|}{ Ochotnica Valley } & \multicolumn{6}{|c|}{ Solinka Valley } \\
\hline & \multirow{2}{*}{$\begin{array}{c}\text { Entire } \\
\text { area } \\
{[\%]}\end{array}$} & \multicolumn{5}{|c|}{ Forest durability classes [\%] } & \multirow{2}{*}{$\begin{array}{c}\text { Entire } \\
\text { area } \\
{[\%]}\end{array}$} & \multicolumn{5}{|c|}{ Forest durability classes [\%] } \\
\hline & & $0-35$ & $35-80$ & $80-150$ & $150-235$ & $>235$ & & $0-35$ & $35-80$ & $80-150$ & $150-235$ & $>235$ \\
\hline$<600$ & 6.7 & 5.6 & 3.1 & 1.3 & 0.7 & 0.0 & 1.4 & 4.4 & 1.1 & 0.5 & 0.2 & 0.4 \\
\hline $600-800$ & 40.4 & 39.8 & 49.7 & 49.0 & 29.0 & 4.8 & 55.0 & 78.7 & 78.0 & 61.7 & 70.5 & 39.3 \\
\hline $800-1000$ & 38.5 & 39.4 & 39.6 & 47.0 & 39.4 & 56.5 & 38.7 & 14.9 & 19.1 & 34.6 & 25.1 & 54.0 \\
\hline$>1000$ & 14.4 & 15.2 & 7.6 & 2.7 & 30.9 & 38.7 & 4.9 & 2.0 & 1.8 & 3.2 & 4.2 & 6.3 \\
\hline Total & 100.0 & 100.0 & 100.0 & 100.0 & 100.0 & 100.0 & 100.0 & 100.0 & 100.0 & 100.0 & 100.0 & 100.0 \\
\hline
\end{tabular}

in forests with the shortest durability period and gradually decreases in forests with a longer durability period.

Research on relationships between land use and altitude, slope and aspect has been undertaken by many authors (Bucała,
2012; Sobala \& Czajka, 2012; Godziek \& Szypuła, 2018). They have determined that in the Beskidy Mts. the share of forest cover in particular periods increases together with the increasing altitude, while the correlation between land use change and aspect has 
been excluded. The results of this study confirm these conclusions.

A specific type of relief could have exerted influence on the analysis of correlation of forest durability classes and slopes. In the Ochotnica Valley the majority of slopes have quite consistent values $\left(15-35^{\circ}\right)$, while in the Solinka Valley slopes with low values occur mainly at its bottom as well as at the top of ridges, whereas slopes above $15^{\circ}$ occupy mainly higher located areas. Forests with short durability period appear mainly in areas located close to the valley bottom and forests with long durability period overgrowing higher located areas on the hillsides. That is probably the reason why the correlation between forest cover durability and slopes is very clear in the Solinka Valley while in the Ochotnica Valley there is no such correlation.

\section{Conclusions}

On the basis of this study the following conclusions can be drawn:

- The quality of results obtained with the use of the method of forest cover durability classes delineation is strongly dependent on the quality of materials used for the analysis and methods of georeferencing applied during data preparation. Map georeferencing errors affect the absolute values of total areas occupied by forests but correctly reflect the tendencies regarding quantitative and spatial changes of forest cover and relationships between forest cover and other elements of the environment over time. Shift errors could be reduced by excluding some cartographical materials from the analysis. In that situation the analysis would involve a shorter period of time and would not present the impact of forest cover ranges at the turn of 18th and 19th centuries on contemporary forest cover durability.

- Maps of forest cover durability are the final product of forest cover change analysis. They make it possible to present the ranges of particular forest durability classes in a transparent way. Owing to these maps, we can present particular stages of forest expansion in a given area and visualize the process of landscape change. Such maps also allow us to analyse spatial distribution of forest durability classes.

- Spatial structure of forest durability classes in the Ochotnica Valley is different in comparison with the Solinka Valley. In the Ochotnica Valley forests are significantly fragmented and the share of forests with long durability period is smaller than in the Solinka Valley. In the Solinka Valley forests with long durability period are dense and occupy circa $2 / 3$ of the valley. This variety results mainly from different accessibility of both valleys.

- In the entire study area, the correlation between the mean height of trees and forest durability classes was detected. The longer forest durability period, the bigger the mean height of trees, whereby the differences in the mean height of trees in neighbouring durability classes are not too big and total circa $2 \mathrm{~m}$. The results of this research have confirmed that the length of time period during which a given area was occupied by forest also exerts influence on the height of trees.

- In both valleys forests with longer durability period occupy areas located at higher altitude. Forests with shorter durability period occur mainly close to the valley bottom (in former farmlands and areas of non-existent villages) and on the ridges (on former mountain meadows). In the Solinka Valley forests with longer durability period overgrow areas with higher slope values, while in the Ochotnica Valley such correlation was not found. In both valleys the occurrence of particular forest durability class was not connected with aspects.

- Specific type of relief could have exerted influence on the analysis of correlation of forest durability classes and DEM data, especially in the case of slopes. In the Ochotnica Valley the variation in slopes is small, while in the Solinka Valley low slopes occur mainly in valleys and slopes above $15^{\circ}$ occur on areas located higher. 
Forests with short durability period appear mainly in areas located close to the valley bottom and forests with long durability period overgrow the slopes of areas located higher. Therefore, that is probably the reason why the correlation between forest cover durability and slopes is very clear in the Solinka Valley while in Ochotnica Valley there is no such correlation.

- The presented method of determination of forest durability classes can allow us to lead further research on distinguishing boundary of forests with long durability period and comparison of biodiversity between forests belonging to different durability classes. These actions can entail better protection of forests with long durability period and improve the process of forest resources management.

Editors' note:

Unless otherwise stated, the sources of tables and figures are the authors', on the basis of their own research.

\section{References}

Affek, A. (2013). Georeferencing of historical maps using GIS, as exemplified by the Austrian Military Surveys of Galicia. Geographia Polonica, 86(4), 375-390. https://doi.org/10.7163/gpol.2013.30

Affek, A. (2015). Skutki krajobrazowe przerwania ciągłości osadnictwa. Prace Komisji Krajobrazu Kulturowego Polskiego Towarzystwa Geograficznego, 28, 47-64. http://yadda.icm.edu.pl/baztech/element/bwmeta1.element.baztech-37530139-ff7e-417e-be28-c6a096604993

Antonarakis, A.S., Richards, K.S., Brasington, J. (2008). Object-based land cover classification using airborne LiDAR. Remote Sensing of Environment, 112(6), 2988-2998. https://doi.org/10.1016/j.rse.2008.02.004

Augustyn, M., Kucharczyk, S. (2008). Analiza stanu zachowania lasów we wsiach Ustrzyki Górne i Wołosate w świetle dokumentów historycznych. Roczniki Bieszczadzkie, 16, 159-178.

Bebi, P., Seidl, R., Motta, R., Fuhr, M., Firm, D., Krumm, F., Conedera, M., Grinzler, C., Wohlgemuth, T., Kulakowski, D. (2017). Changes of forest cover and disturbance regimes in the mountain forests of the Alps. Forest Ecology and Management, 338, 3-56. https://doi.org/10.1016/j.foreco.2016.10.028.

Bucała, A. (2012). Wspótczesne zmiany środowiska przyrodniczego dolin potoków Jaszcze i Jamne w Gorcach. Warsaw. Prace Geograficzne, 231, Warszawa: Instytut Geografii i Przestrzennego Zagospodarowania PAN.

Bucała, A., Starkel, L. (2013). Postępująca recesja rolnictwa a zmiany w środowisku przyrodniczym polskich Karpat. Przeglad Geograficzny, 85(1), 15-29.

Bucała-Hrabia, A. (2018). Land use changes and their catchment-scale environmental impact in the Polish Western Carpathians during transformation from centrally planned do free-market economics. Geographia Polonica, 91(2), 171-196. https://doi.org/10.7163/GPol.0116.

Czajka, S. (1987). Ochotnica. Dzieje gorczańskiej wsi 1416-1986. Jelenia Góra: Karkonoskie Towarzystwo Naukowe.

ESRI, (2018). ArcGIS Desktop: Release 10.7. Redlands, CA: Environmental Systems Research Institute.

Fritz, O., Gustafsson, L., Larsson, K. (2008). Does forest continuity matter in conservation? - A study of epiphytic lichens and bryophytes in beech forests of southern Sweden. Biological Conservation, 141(3), 655-668. https://doi.org/10.1016/j.biocon.2007.12.006.

Godziek, J., Szypuła, B. (2018). A study of changes in forest cover in the Ochotnica valley in the 19th-20th centuries based on cartographic materials. Prace Komisji Krajobrazu Kulturowego, 39(1), 189-206. https://doi.org/10.30450/201811

Griffiths, P., Kuemmerle, T., Baumann, M., Radeloff, V.C., Abrudan, I.V., Lieskovsky, J., Munteanu, C., Ostapowicz, K., Hostert, P. (2014). Forest disturbances, forest recovery, and changes in forest types 
across the Carpathian ecoregion from 1985 to 2010 based on Landsat image composites. Remote Sensing of Environment, 151, 72-88. https://doi.org/10.1016/j.rse.2013.04.022

GUGIK, (2019). Dane centralnego zasobu geodezyjnego i kartograficznego. Główny Urząd Geodezji

i Kartografii. Retrieved from http://www.gugik.gov.pl/pzgik [15 April 2019]

Kaim, D., Kozak, J., Kolecka, N., Ziółkowska, E., Ostafin, K., Ostapowicz, K., Gimmi, U., Munteanu, C., Radeloff, V.C. (2016). Broad scale forest cover reconstruction form historical topographic maps. Applied Geography, 67, 39-48. https://doi.org/10.1016/j.apgeog.2015.12.003

Kolecka, N., Kozak, J., Kaim, D., Dobosz, M., Ginzler, CH., Psomas, A. (2015). Mapping secondary forest succession on abandoned agricultural land with LiDAR point clouds and terrestrial photography. Remote Sensing, 7(7), 8300-8322. https://doi.org/10.3390/rs70708300

Kolecka, N., Kozak, J., Kaim, D., Dobosz, M., Ostafin, K., Ostapowicz, K., Wężyk, P., Price, B. (2017). Understanding farmland abandonment in the Polish Carpathians. Applied Geography, 88, 62-72. https://doi.org/10.1016/j.apgeog.2017.09.002

Kondracki, J. (2011). Geografia regionalna Polski. Warszawa: Wydawnictwo Naukowe PWN.

Konias, A. (2000). Kartografia topograficzna Ślaska Cieszyńskiego i zaboru austriackiego od II połowy XVIII wieku do poczqtku XX wieku. Prace Naukowe Uniwersytetu Ślqaskiego w Katowicach nr 1866. Katowice: Wydawnictwo Uniwersytetu Śląskiego.

http://yadda.icm.edu.pl/yadda/element/bwmeta1.element.agro-article-cded1f52-051f-4ff3-9218-cce71cd8f3fe

Kowalski, P., Siwek, J. (2013). Polskie mapy topograficzne do użytku powszechnego - ćwierć wieku sukcesów czy niepowodzeń? Polski Przeglad Kartograficzny 45(4), 334-343.

http://yadda.icm.edu.pl/yadda/element/bwmeta1.element.baztech-37530139-ff7e-417e-be28-c6a096604993

Kozak, J. (2003). Forest cover change in the Western Carpathians in the past 180 years - a case study in the Orawa region in Poland. Mountain Research and Development, 23, 369-375. https://doi.org/10.1659/0276-4741(2003)023[0369:FCCITW]2.0.CO;2

Krukar, W. (2017). Środowisko geograficzne. In P. Luboński (Ed.) Bieszczady - przewodnik (pp. 21- 33). Pruszków: Oficyna Wydawnicza Rewasz.

Kryciński, S., Gqusiorowski, A., Olszański, T.A. (2017). Słownik miejscowości. In P. Luboński (Ed.) Bieszczady - przewodnik (pp. 263-401). Pruszków: Oficyna Wydawnicza Rewasz.

Łajczak, A., Margielewski, W., Rączkowska, Z., Świechowicz, Z. (2014). Contemporary geomorphic processes in the Polish Carpathians under changing human impact. Episodes, 37,(1), 21-32.

https://doi.org/10.18814/epiiugs/2014/v37i1/003

Mapire, (2019). Historical maps online. Retrieved from http://mapire.eu/en [15 April 2019]

Mapster, (2019). Old maps of Poland and Central Europe. Retrieved from http://igrek.amzp.pl/index.php [15 April 2019]

Mastronunzio, M., Dai Prà, E. (2016). Who Needs Mitteleuropa Old Maps? Present-day Applications of Habsburg Cartographic Heritage In G. Gartner, M. Jobst, H. Huang, (Eds.), Progress in Cartography. Lecture Notes in Geoinformation and Cartography. (pp. 305-318). Cham: Springer. https://doi.org/10.1007/978-3-319-19602-2_19

Molnár, G., Timár, G. (2009). Mosaicking of the 1:75,000 sheets of the Third Military Survey of the Habsburg Empire. Acta Geodaetica et Geophysica Hungarica, 44(1), 115-120. https://doi.org/10.1556/AGeod.44.2009.1.11

Molnár, G., Timár, G., Biszak, E., (2014). Can the First Military Survey maps of the Habsburg Empire (1763-1790) be georeferenced by an accuracy of 200 meters? 9th International Workshop on Digital Approaches to Cartographic Heritage, Budapest, 4-5 September 2014.

Munteanu, C., Kuemmerle, T., Boltiziar, M., Butsic, V., Gimmi, U., Halada, L., Kaim, D., Király, G., KonkolyGyuró, E., Kozak, J., Lieskovský, J., Mojses, M., Müller, D., Ostafin, K., Ostapowicz, K., Shandra, O., Štych, P., Walker, S., Radeloff, V.C. (2014). Forest and agricultural land change in the Carpathian region - A meta-analysis of long-term patterns and drivers of change. Land Use Policy, 38, 685-697.

https://doi.org/10.1016/j.landusepol.2014.01.012 
Munteanu, C., Kuemmerle, T., Keuler, N.S., Müller, D., Balázs, P., Dobosz, M., Griffiths, P., Halada, L., Kaim, D., Király, G., Konkoly-Gyuró, É., Kozak, J., Leskovsky, J., Ostafin, K., Ostapowicz, K., Shandra, O., Radeloff, V.C. (2015). Legacies of 19th century land use shape contemporary forest cover. Global Environmental Change, 34, 83-94. https://doi.org/10.1016/j.gloenvcha.2015.06.015

Nita, J., Myga-Piątek, U., Absalon, D. (2015). Assessment of the exposure of tourism-related landscape values of the Silesian Beskids based on computer visualization. In M. Luc, U. Somorowska, J. Szmańda (Eds.) Landscape Analysis and Planning (pp. 45-58). Cham: Springer. https://doi.org/10.1007/978-3-319-13527-4_3

Orczewska, A. (2015). Czynniki i procesy determinujace długoterminowe zmiany rozmieszczenia gatunków leśnych w krajobrazie. Problemy Ekologii Krajobrazu, 39, 59-70.

Pietkiewicz, S. (1975). Austriackie topograficzne mapy Tatr i Przedtatrza od końca XVIII do końca XIX stulecia i ich dokładność. Prace i Studia IG UW, 16, 95-109.

Plit, J. (2016). Krajobrazy kulturowe Polski i ich przemiany. Prace Geograficzne, 253, Warszawa: Instytut Geografii i Przestrzennego Zagospodarowania PAN.

Podobnikar, T. (2009). Georeferencing and quality assessment of Josephine survey maps for the mountainous region in the Triglav National Park. Acta Geodaetica et Geophysica Hungarica, 44(1), 49-66. https://doi.org/10.1556/AGeod.44.2009.1.6

Price, B., Kaim, D., Szwagrzyk, M., Ostapowicz, K., Kolecka, N., Schmatz, D.R., Wypych, A., Kozak, J. (2017). Legacies, socio-economic and biophysical processes and drivers: the case study of future forest cover expansion in the Polish Carpathians and Swiss Alps. Regional Environmental Change, 17(8), 2279-2291. https://doi.org/10.1007/s10113-016-1079-z

Prokop, P. (2017). The first medium-scale topographic map of Galicia (1779-1783) - survey, availability and importance. Geographia Polonica, 90(1), 97-104. https://doi.org/10.7163/GPol.0081

QGIS, (2019). QGIS (Geographic Information System v. 3.6.1). QGIS Development Team. Retrieved from Open Source Geospatial Foundation Project - http://qgis.osgeo.org.

Rygiel, Z. (2017). Kolejki leśne w Bieszczadach In P. Luboński (Ed.) Bieszczady - przewodnik (pp. 107-113). Pruszków: Oficyna Wydawnicza Rewasz.

Sabatini, F.M., Burrascano, S., Keeton, W.S., Levers, CH., Linder, M., Pötzschner, F., Verkerk, P.J., Bauhaus, J., Buchwald, E., Chaskovsky, O., Debaive, N., Horváth, F., Garbarino, M., Grigoriadis, N., Lombardi, F., Duarte, I.M., Meyer, P., Mldteng, R., Mikac, S., Mikoláš, M., Motta, R., Mozgeris, G., Nunes, L., Panayotov, M., Ódor, P., Ruete, A., Simovski, B., Stillhard, J., Svoboda, M., Szwagrzyk, J., Tikkanen, O., Volosyanchuk, R., Vrska, T., Zlatanov, T., Kuemmerle, T. (2018). Where are Europe's last primary forests?. Diversity and Distributions, 24(10), 1-14. https://doi.org/10.1111/ddi.12778

Skaloš, J., Engstová, B., Trpáková, B., Šantrůčková, M. (2012). Long-term changes in forest cover 17802007 in central Bohemia, Czech Republic. European Journal of Forest Research, 131(3), 871-884. https://doi.org/10.1007/s10342-011-0560-y

Sobala, M. (2018). Pasture landscape durability in Beskid Mountains (Western Carpathians, Poland). Geographia Polonica, 91(2), 197-215. https://doi.org/10.7163/GPol.0117

Sobala, M., Czajka, B. (2012). The use of digital terrain model in the study of distribution of cultural landscape elements based on the example of the Silesia Beskid. Contemporary Trends in Geoscience, 1, 81-85. https://doi.org/10.2478/ctg-2012-0012

Sobala, M., Rahmonov, O., Myga-Piątek, U. (2017). Historical and contemporary forest ecosystem changes in the Beskid Mountains (southern Poland) between 1848 and 2014. iForest - Biogeosciences and Forestry, 10, 939-947. https://doi.org/10.3832/ifor2418-010

Soja, M. (2008). Cykle rozwoju ludności Karpat Polskich w XIX i XX wieku. Kraków: Instytut Geografii i Gospodarki Przestrzennnej UJ.

Solon, J., Borzyszkowski, J., Bidłasik, M., Richling, A., Badora, K., Balon, J., Brzezińska-Wójcik, T., Chabudziński, Ł., Dobrowolski, R., Grzegorczyk, I., Jodłowski, M., Kistowski, M., Kot, R., Krąż, P., Lechnio, J., Macias, A., Majchrowska, A., Malinowska, E., Migoń, P., Myga-Piątek, U., Nita, J., Papińska, E., 
Rodzik, J., Strzyż, M., Terpiłowski, S., Ziaja, W. (2018). Physico-geographical mesoregions of Poland: Verification and adjustmennt of boundaries on the basis of contemporary spatial data. Geographia Polonica, 91(2), 143-170. https://doi.org/10.7163/GPol.0115

Starkel, L. (1972). Zachodnie Karpaty Zewnętrzne (fliszowe). In M. Klimaszewski (Ed.), Geomorfologia Polski, vol. 1 (pp. 52-115). Warszawa: Państwowe Wydawnictwo Naukowe.

Szymura, T.H., Dunajski, A., Ruczakowska, A.M. (2010). Zmiany powierzchni lasów na obszarze Karkonoskiego Parku Narodowego w okresie 1747-1977. Opera Corcontica, 47, 159-166.

Timár, G., (2009). System of the 1:28,800 scale sheets of the Second Military Survey in Tyrol and Salzburg. Geodaetica et Geophysica Hungarica, 44(1), 95-104. https://doi.org/10.1556/AGeod.44.2009.1.9

Timár, G., Biszak, S. (2010). Digitizing and georeferencing of the historical cadastral maps (1856-60) of Hungary. In E. Livieratos, G Gartner (Eds.), 5th International Workshop on Digital Approaches in Cartographic Heritage, Vienna, Austria (pp. 559-564).

Timár, G., Biszak, S., Szekely, B., Molnár, G. (2011). Digitized maps of the Habsburg military surveys: Overview of the project of ARCANUM Ltd. (Hungary). In M. Jobst (Ed.), Preservation in digital cartography (pp. 273-283). Lecture Notes in Geoinformation and Cartography, Berlin-Heidelberg: Springer. https://doi.org/10.1007/978-3-642-12733-5_14

WIG, (1938). Katalog map. Warszawa: Wojskowy Instytut Geograficzny.

Wolski, J. (2007). Przekształcenia krajobrazu wiejskiego Bieszczadów Wysokich w ciagu ostatnich 150 lat. Prace Geograficzne, 214, Warszawa, Instytut Geografii i Przestrzennego Zagospodarowania im. Stanisława Leszczyckiego PAN.

Wolski, J. (2016). Kartografia topograficzna Bojkowszczyzny Zachodniej (1772-1939). In J. Wolski, (Ed.), Bojkowszczyzna Zachodnia - wczoraj, dziś i jutro, Tom 1 (pp. 107-174). Warszawa: Instytut Geografii i Przestrzennego Zagospodarowania im. Stanisława Leszczyckiego PAN.

\section{Maps and data}

Karte des Königreiches Galizien und Lodomerien (1779-1783). Sections: 36, 107, 108, 1:28,800. Vienna: Austrian State Archive, Military Archive.

Mapa Taktyczna Polski. Sections: A51 B30 Zakopane (1934), A50 B30 Rabka (1934), A52 B34 Łupków (1938), A52 B35 Dołżyca (1937), 1:100,000. Warsaw: Wojskowy Instytut Geograficzny.

Mapa topograficzna. Sections: 183.14 Nowy Targ (1979), 183.23 Ochotnica Dolna (1978), 195.22 Cisna (1982), 195.24 Kalnica (1982), 1:25,000. Warsaw: Surveyor General of Poland.

Militär Aufnahme von Galizien und der Bukovina. Sections: W 09_13, W 09_14, W 18_10, W 18_11, W 19_10, W 19_11(1861-1864), 1:28,800. Vienna: Austrian State Archive, Military Archive.

NMPT, (2014). Digital surface model. Warsaw: Surveyor General of Poland.

NMT, (2014). Digital elevation model. Warsaw: Surveyor General of Poland.

Orthophotomap, (2015-2018). Warsaw: Surveyor General of Poland. 